Review article

Paediatrics Today 2016;12(1):131-138

DOI $10.5457 / \mathrm{p} 2005-114.149$

\title{
ABSENCE EPILEPSY - ELECTROCLINICAL FEATURES AND CURRENT ADVANCES
}

\author{
Dimitrije NIKOLIĆ ${ }^{1}$, Marijana MARINKOVIĆ ${ }^{2}$, Biljana MEĐO $^{1}$, Kristina JOVANOVIĆ ${ }^{1}$
}

${ }^{1}$ Belgrade University Medical Faculty Belgrade, Serbia, ${ }^{2}$ Clinical Centre

Zemun, Belgrade, Serbia

Correspondence:

dimitrije.nikolic@udk.bg.ac.rs

Tel.: + 381112060702

Fax.: + 381112684672

Received: June 16, 2016

Accepted: August 28, 2016

Key words: Absence seizures • Electroencephalography (EEG) - Childhood absence epilepsy - Juvenile absence epilepsy.

\begin{abstract}
The purpose of this article is to provide an overview of the electroclinical features and pathophysiological findings, as well as the neuropsychological characteristics of absence epilepsies. Absence seizures are primary generalized, non-convulsive seizures. The classical clinical manifestations of typical absence seizures are a transient impairment of consciousness (with abrupt onset and offset) accompanied by staring, blinking and various forms of head/limb automatism. Atypical absence attacks are characterized by a milder beginning and end of the attack, more expressed changes in muscular tone, less severe disorders of consciousness, and longer duration compared to typical attacks. EEG findings in absence epilepsies have a characteristic pattern, demonstrating generalized spike and wave complexes that are typically 2.5-4 Hz. Treatment depends on the type of epilepsy, but usually includes valproic acid and ethosuximide. Because of their benign nature and lack of clinical presentation that resembles "real" epilepsy, absence attacks are often interpreted as daydreaming or simply a lack of attention, and therefore often the first signs of the disease are often not recognized. Conclusion: A better understanding of absence epilepsies is very important in order to develop strategies that will improve these children's quality of life.
\end{abstract}

\section{Introduction}

Epilepsy, the most common neurological disease, is a disorder of the brain characterized by an enduring predisposition to generate epileptic seizures. Depending on the type of epilepsy and its etiology, they may be expressed in various ways, including disorders of movement, sensibility, perception, autonomous function, consciousness and other functions, and implicate a variety of cognitive, psychological and social consequences (1).

The prevalence and incidence of epilepsy differ in terms of demographic factors, including age, gender, race and socioeco- nomic status. The incidence of this disease differs among more or less developed countries and approximately ranges from 41 to $187 / 100,000$ in general. In developed countries, the prevalence of epilepsy increases as age increases, while in developing countries, the prevalence of epilepsy generally peaks in adolescence and early adulthood (2). Although each type of epilepsy has its own peculiarities and each is worthy of attention in its own way, over the last few decades, a great deal of attention has been paid to absence epilepsies, more precisely to their genetic, behavioral and cognitive aspects. 
The purpose of this article is to provide an overview of the electroclinical features and pathophysiological findings, as well as the neuropsychological characteristics of absence epilepsies.

\section{Absence epilepsies \\ History}

Absences were described for the first time in 1702 by Poupart, but the term "epileptic absence seizure" was not used until 1824. In subsequent years there were several attempts to describe this disorder in the most accurate way. In 1881 Gowers said that absences were "non convulsive" seizures, and in 1906 Fridman reported a long-term favorable prognosis for absence epilepsy. In 1916 Sauer used the term "pyknolepsy" for the first time (the Greek word pycnos meaning "accumulated, condensed", probably due to the tendency to frequent repetition of the attacks). However, even after 300 years from the time when it was first described, the classification, pathophysiology, treatment and prognosis of absence epilepsy are still the subject of great interest (3-7).

\section{Pathophysiology}

The pathophysiology mechanism that leads to absence seizures has been being explored for almost a century, but in spite of all efforts the debate is still on. Experiments on animal models and research involving humans show that by stimulating certain structures in the thalamus and cortex, the characteristic absence discharge can be provoked. There are three main components of the thalamocortical network:

- Thalamocortical relay neurons (from the thalamus to III-IV and V-VI layers of the cortex).

- Layer VI pyramidal cells of the cortex (which send back excitatory inputs to the thalamus).
- Inhibitory GABA neurons in the thalamus (receiving excitatory inputs from the axon collaterals of the reciprocal thalamocortical and corticothalamic pathways). Once activated, these GABA neurons send inhibitory inputs to the thalamus and also to each other, but not to the cortex (8).

What does this mean in practice? When this formation functions without interference, the thalamocortical neurons lead to excitation of the GABA neurons. This activation, through the calcium channels, leads to the opening of the sodium channels and initiates action potential. Activation of the GABA neurons causes an inhibitory postsynaptic potential in the thalamocortical neurons. During this hypopolarisation, the calcium channels recover from inactivation, re-open, depolarize the cell membrane and prepare for a new cycle of discharge. These developments are manifested on EEG by the appearance of a synchronized oscillation frequency of about $10 \mathrm{~Hz}$ (8-10).

However, a disorder in this excitatory inhibitory cycle will lead to the occurrence of the spike-wave complexes of less frequency that are characteristic for absence epilepsy. Genetic research has shown that there is a disturbance in the synthesis of calcium channels in GABA neurons. This type of mutation in the genes encoding the formation of calcium-dependent channel subunits has been demonstrated in several studies. Mutations that lead to enhanced features result in a loss of inhibition in the thalamo-cortical network, while mutations that cause reduced activity lead to increased excitation and therefore increase the likelihood of seizures. Mutations can be found in different genes, one or more, even in the same patient. For example, in children with early onset absence epilepsy, mutations of the SLC2A1 gene, which is responsible for the synthesis of GLUT1 transporter, have been shown, 
Table 1: Genes involved in the epileptogenesis of idiopathic absence epilepsies

\begin{tabular}{lllll}
\hline Gene & Protein & Protein mutation & Functional study & Clinical features \\
\hline GABRA1 & $\begin{array}{l}\text { a1subunit of the } \\
\text { GABAA receptor }\end{array}$ & $\begin{array}{l}\text { Premature } \\
\text { stop codon }\end{array}$ & No GABAA receptor current & CAE \\
\hline GABRAB3 & $\begin{array}{l}\text { B3 subunit of the } \\
\text { GABAA receptor }\end{array}$ & $\begin{array}{l}\text { P11S, S15F, } \\
\text { G32R }\end{array}$ & $\begin{array}{l}\text { Altered protein maturation, topology, } \\
\text { assembly and subcellular localization of } \\
\text { GABA receptors }\end{array}$ & CAE \\
\hline CACNA1A & $\begin{array}{l}\text { a1A subunit of } \\
\text { P/Q channels }\end{array}$ & R1820stop & Reduced Ca2+ current & $\begin{array}{l}\text { Severe phenotype } \\
\text { of absence seizures } \\
\text { and ataxia }\end{array}$ \\
\hline CACNA1G & $\begin{array}{l}\text { a1G subunit } \\
\text { of LVA channels }\end{array}$ & $\begin{array}{l}\text { A570V/A1099T } \\
\text { /R1243Q }\end{array}$ & $\begin{array}{l}\text { Increased Ca2+ current and faster } \\
\text { inactivation decay rates/No alteration } \\
\text { in Ca+ currents }\end{array}$ & $\begin{array}{l}\text { JME and with a } \\
\text { history of early CAE }\end{array}$ \\
\hline CACNA1H & $\begin{array}{l}\text { a1H subunit } \\
\text { of LVA channels }\end{array}$ & $\begin{array}{l}\text { Many different } \\
\text { mutations }\end{array}$ & $\begin{array}{l}\text { Predicted to change the charge status of } \\
\text { the channel and phosphorylation site/ } \\
\text { Predicted to affect transcription factor } \\
\text { binding site }\end{array}$ & $\begin{array}{l}\text { CAE } \\
\text { SLC2A1 }\end{array}$ \\
$\begin{array}{l}\text { Glut1 glucose } \\
\text { transporter }\end{array}$ & $\begin{array}{l}\text { R223P, S324L, } \\
\text { R126C }\end{array}$ & $\begin{array}{l}\text { Decreased level of glucose transport } \\
\text { Glutamate } \\
\text { dehydrogenase }\end{array}$ & R221C & $\begin{array}{l}\text { Early onset } \\
\text { absence epilepsy }\end{array}$ \\
\hline
\end{tabular}

*Yalcın O. Genes and molecular mechanisms involved in the epileptogenesis of idiopathic absence epilepsies. Seizure 2012;21:7986; $\mathrm{CAE}=$ Childhood absence epilepsy, JME=Juvenile myoclonic epilepsy.

while in children with idiopathic childhood epilepsy, mutations in GABR and CACNA genes were found (Table 1) (8-11).

\section{Electroencephalography (EEG)}

EEG findings in absence epilepsies have a characteristic pattern. During the absence seizure episode 3-5 $\mathrm{Hz}$ spike -wave complexes (SWC) are registered. These types of ictal EEG discharges were first related to absence seizures in 1947, when bilateral, synchronized SWC were provoked by stimulation of nuclei thalami in cats, and the same pattern was registered by placing electrodes in the thalamus of a child with absences in 1953 (12, 13). Finally, several years later the thalamo-cortical theory was confirmed by registering 2.5-4 SWC primarily in the cortex (14). These EEG changes may be accompanied by other EEG features, such as: ab- normal background activity, multiple SWC, focal discharges, delta activity in posterior leads, depending on the type of epilepsy (15).

\section{Classification}

Absence seizures are primary generalized non-convulsive seizures. Compared to the Classification of the International League against Epilepsy (ILAE) from 1981, when only typical and atypical absences were known, the revised classification recognizes two more types of absence seizures, with special features: myoclonic absence seizures and eyelid myoclonia with absences (16).

\section{Typical absence seizures}

The main clinical manifestation of typical absences is abrupt onset and termination of consciousness impairment, followed by staring, 
Table 2 Main epileptic syndromes with typical absences

\begin{tabular}{lllll}
\hline Syndrome & $\begin{array}{l}\text { Impairment of } \\
\text { consciousness }\end{array}$ & $\begin{array}{l}\text { Other type } \\
\text { of seizure }\end{array}$ & Drug of choice & $\begin{array}{l}\text { Duration } \\
\text { of treatment }\end{array}$ \\
\hline $\begin{array}{l}\text { Childhood } \\
\text { absence epilepsy }\end{array}$ & Severe & Rarely other types & $\begin{array}{l}\text { Valproic acid } \\
\text { Ethosuximide } \\
\text { Lamotrigine }\end{array}$ & 1-3 years \\
\hline $\begin{array}{l}\text { Juvenile } \\
\text { absence epilepsy }\end{array}$ & Severe & $\begin{array}{l}\text { GTC, } \\
\text { Myoclonic }\end{array}$ & $\begin{array}{l}\text { Valproic acid } \\
\text { Lamotrigine } \\
\text { Ethosuximide }\end{array}$ & Lifelong \\
\hline $\begin{array}{l}\text { Myoclonic } \\
\text { absence epilepsy }\end{array}$ & Severe & GTC, & Valproic acid & Clonazepam \\
Lamotrigine & Lifelong \\
$\begin{array}{l}\text { Juvenile } \\
\text { myoclonic epilepsy }\end{array}$ & Mild & GTC, myoclonic & $\begin{array}{l}\text { Valproic acid } \\
\text { Lamotrigine } \\
\text { Clonazepam }\end{array}$ & Lifelong \\
\hline $\begin{array}{l}\text { Eyelid myoclonia } \\
\text { with absences } \\
\text { (Jeavons Syndrome) }\end{array}$ & Mild & Myoclonic, & $\begin{array}{l}\text { Valproic acid } \\
\text { Clonazepam } \\
\text { Ethosuximide } \\
\text { Lamotrigine }\end{array}$ & Lifelong \\
\hline $\begin{array}{l}\text { Perioral myoclonia } \\
\text { with absences }\end{array}$ & Moderate & $\begin{array}{l}\text { Myoclonic, Absence } \\
\text { status, Rarely GTC }\end{array}$ & $\begin{array}{l}\text { Valproic acid } \\
\text { Clonazepam } \\
\text { Ethosuximide } \\
\text { Lamotrigine }\end{array}$ & Lifelong for \\
\hline
\end{tabular}

GTC=Generalized tonic-clinic seizures.

blinking and different forms of head/limb automatism. They are easily provoked by hyperventilation (HV), while seizures provoked by photo-stimulation (FS) are rare. EEG shows a generalized $>2.5 \mathrm{~Hz}$ spike and slow wave discharges lasting 4-25 seconds. Interictal EEG is normal. Most children with typical absence seizures have a normal neurological examination and intelligence. These types of seizures are characteristic for childhood absence epilepsy and juvenile absence epilepsy. Other epileptic syndromes with typical absence seizures are listed in Table $2(17,18)$.

\section{Atypical absence seizures}

Atypical absence attacks are characterized by the milder beginning and end of the at-

\section{Table 3 Epileptic syndromes with atypical absences}

\begin{tabular}{lllll}
\hline Syndrome & $\begin{array}{l}\text { Age } \\
\text { of onset }\end{array}$ & $\begin{array}{l}\text { Other types } \\
\text { of seizures }\end{array}$ & Other characteristics & Therapy \\
\hline $\begin{array}{l}{ }^{*} \text { Lennox-Gastaut } \\
\text { syndrome }\end{array}$ & $\begin{array}{l}\text { Early } \\
\text { childhood }\end{array}$ & Tonic, Atonic & $\begin{array}{l}\text { Cognitive and behavioral } \\
\text { abnormalities }\end{array}$ & $\begin{array}{l}\text { Antiepileptic drugs (Depends } \\
\text { on seizure type) }\end{array}$ \\
\hline *Dravet syndrome & First year & $\begin{array}{l}\text { FS, Myoclonic, } \\
\text { ES }\end{array}$ & $\begin{array}{l}\text { Cognitive and } \\
\text { behavioral abnormalities, } \\
\text { Neuropsychological impairment }\end{array}$ & $\begin{array}{l}\text { Antiepileptic drugs, } \\
\text { Ketogenic diet }\end{array}$ \\
\hline $\begin{array}{l}\text { Other epileptic } \\
\text { encephalopathies }\end{array}$ & Any time & $\begin{array}{l}\text { Multiple forms } \\
\text { of seizure }\end{array}$ & Neuropsychological impairment & $\begin{array}{l}\text { Antiepileptic drugs (Depends } \\
\text { on seizure type) }\end{array}$ \\
\hline GEFS+ & Childhood & FS, GTC & $\begin{array}{l}\text { Learning difficulties and } \\
\text { behavioral problems }\end{array}$ & $\begin{array}{l}\text { Antiepileptic drugs (Depends } \\
\text { on seizure type) }\end{array}$ \\
\hline
\end{tabular}

"Type of epileptic encephalopathy; FS=Febrile seizures, ES=Epileptic status; GEFS+=Generalized epilepsy with febrile seizures; $\mathrm{GTC}=$ Generalized tonic-clonic seizures. 
tack, more expressed changes in muscular tone, less severe disorders of consciousness, and longer duration compared to typical attacks. They are more likely to occur during drowsiness and are rarely provoked by hyperventilation and photo-stimulation. EEG shows generalized slow spike wave complexes $<2.5 \mathrm{~Hz}$, that are irregular, asymmetrical and of lower amplitude. Interictal EEG may be normal or it may show irregular background activity. This type of absence usually occurs within a more complex epileptic syndrome, such as Dravet syndrome, Lennox-Gastaut and others (Table 3) (17-19).

\section{Absences with special features}

When the ILAE revised the Classification of Epilepsy and Epileptic Disorders in 2010, a special group of absence attacks were singled out: absence myoclonic seizures and eyelid myoclonia with absences (16). Absence myoclonic seizures are actually typical absences combined with myoclonic jerks of the shoulders, arms and legs that may occur at all stages of the attack. Jerks are usually bilateral but can be unilateral or asymmetric. Seizures usually last from 10-60 seconds. The characteristic EEG findings are generalized spike-wave complexes, frequency of 3-4 Hz. This type of attack may be associated with other seizure semiology within different epileptic syndromes (18). Myoclonia of the eyelids with absences is characterized, as seen in the title, by striking eyelid myoclonia with a upward bulb deviation, and is most often provoked by closing the eyes (off phenomena). The ictal EEG pattern includes multiple, generalized spike-wave complexes with periodic discharges in the occipital region, which may provoke generalized discharges $(18,20)$.

\section{Absence epilepsy disorders}

As already mentioned, absence attacks occur in a variety of epileptic disorders, among which the most common are childhood absence epilepsy and juvenile absence epilepsy. Childhood absence epilepsy (CAE) belongs to the group of idiopathic generalized epilepsy and it is the most common form of epilepsy in children, with an incidence of $10 \%-17 \%$ of all epilepsy in school age children. It occurs between the ages of 4-10, and more frequently in girls, in a ratio of $3: 1$. In most patients there is a positive family history for some epileptogenic disorder, so it is considered that the basis of the disease is a genetic cause. It is characterized by recurrent typical absence seizures, which may be very frequent, so they may be repeated a dozen times a day. The main feature is impairment of consciousness and activity, which suddenly begins and ends abruptly. In most patients, seizures cause complete activity interruption, but in some cases the patient's activities may continue in a modified form $(15,18,21)$.

The semiology of absence seizures, that are characterized by sudden beginning or end, a short and non-convulsive nature and normal continuation of activity, is often interpreted by the environment or the patients themselves as a lack of attention, daydreaming or the absent mindedness of a willful child. In fact, this is the most common reason for late diagnosis of CAE. The presence of automatisms is more frequent in cases of long-lasting attacks or during hyperventilation, and their presence does not depend on age or state of consciousness, and may not occur during each attack. Mild tonic or clonic movements mostly occur in the first few seconds of the attack. Pallor is common, while incontinence rarely occurs. The length of the attack depends on a number of factors, such as: hyperventilation, sleep deprivation, severe mental stimulus, use of drugs and others, but is usually from 5 to 20 seconds. Duration of the attack less than 4 and more than 20 seconds is not considered typical and is one of the exclusion criteria for CAE diagnosis $(15,21)$. 
The EEG pattern in CAE is characterized by the occurrence of bilateral, symmetrical and synchronized $3 \mathrm{~Hz}$ spike-wave complex discharges during the attack, which rapidly begin and end abruptly. Interictal findings are mostly normal, although it has been shown that in over $90 \%$ of patients intermittent short generalized spike-wave discharges are seen. This finding represents the EEG marker for childhood absence epilepsy. Discharges greater than $4 \mathrm{~Hz}$ and longer than 3-4 seconds indicate a worse prognosis and frequently indicate a more serious epileptic disorder $(15,18)$.

The CAE therapies of choice are ethosuximide and valproic acid, but good results are achieved with lamotrigine, although there are many side effects. Data exist that confirm that levetiracetam is also efficient in CAE. Carbamazepine, vigabatrin and tiagabine are contraindicated in the treatment of absence seizures, irrespective of cause and severity. Complete seizure control is achieved in 50\%$70 \%$ of patients within a few weeks $(15,20$ 24).

Juvenile absence epilepsy has its onset between 10-15 years, with female predominance. It is characterized by the appearance of typical absence attacks, with the fact that, unlike CAE, seizures here are often accompanied by eyelid myoclonia and automatism that appears a few seconds after the changes in EEG. Compared with absences in CAE, attacks occur less often but last longer (up to 30 seconds, on average 15s) and characteristically occur after awakening. As in CAE, impaired consciousness occurs abruptly, activities are interrupted, but in longer-lasting attacks it may continue to a certain extent. What characterizes JAE is the appearance of generalized tonic-clonic seizures (GTC) seizures (for $>80 \%$ of patients), which occur rarely and usually after waking up. However, it quite often happens that GTC attacks cause the child to be brought to a doctor be- cause absences previously present were not recognized in time. Precipitating factors for the appearance of GTC are sleep deprivation, alcohol consumption, tiredness, and severe excitement. In 15\%-20\% of patients the occurrence of myoclonic jerks have been reported, that occur most frequently in the afternoon when the child is tired $(18,25)$.

EEG findings imply generalized spike or multiple spike wave complexes, frequency 3-5 Hz, whereas the background activity in general remains normal (25). JAE, unlike CAE, is a lifelong diagnosis. Although in $80 \%$ of cases good seizure control can be achieved, mostly in reducing the frequency and duration of seizures, discontinuation of therapy in many patients leads to recurrence of attacks $(18,25)$.

The treatments of choice for JAE are primarily valproic acid and lamotrigine, in the form of dual therapy. Ethosuximide and other drugs, such as levetiracetam and topiramate, give good results. Use of vigabatrin, carbamazepine and phenytoin has been considered contraindicated because it was shown that they may aggravate seizures (25-27).

\section{Cognitive and behavioral development}

Although absence epilepsies respond well to therapy, and seizure control is achieved relatively quickly, what they have in common are the various social, cognitive and behavioral problems that often occur. It is clear that children who start treatment on time achieve better control of the disease and therefore have fewer consequences.

From the large number of studies that have addressed the behavioral aspects of absence epilepsy, it appears that most common problems are caused by alterations in attention, hyperactivity, reading, solving school tasks and similar problems. Earlier, it was believed that most children with epilepsy have a cognitive problem before diagnosis, but 
that children with CAE do not belong to this group. However, research in the last 15 years assures us that this is not entirely true. Therefore, the question arises whether all these deficiencies arise as a result of genetic predisposition, the disease itself or maybe the use of medications that, if taken in early childhood, may affect cognitive development? The answer to this question is still a mystery, but what has been proven is that early diagnosis and therefore early detection of these problems allows cognitive therapy and educational support, if required, to begin on time (18, 21, 28-30).

Because of its benign nature and lack of a clinical presentation that resembles "real" epilepsy, absence attacks are often interpreted as daydreaming or simply a lack of attention, and therefore the first signs of the disease are often not recognized, so these children come to a doctor only when a different semiology of attacks occurs. In this process valuable time for treatment is lost and therefore the chance for a favorable prognosis is reduced.

\section{Conclusion}

If there are dilemmas about whether a child is daydreaming or having absence seizures, here are a few key differences to look for. Daydreaming: presumably happens when the child is bored (during a long class or while sitting at home); it usually comes on slowly, with warning (may go from paying attention, to slightly absent, to daydreaming); it can be interrupted; it tends to continue until something or someone stops it. Absence seizures: occur at any time of the day, even during activity; usually ensue out of the blue, without warning; they cannot be intercepted; they terminate on their own in 20 seconds. A better understanding of the course of absence seizures and their syndromes is immensely important for developing strategies that im- prove these children's quality of life and the lives of their families.

Authors' contributions: Conception and design: DN, $\mathrm{MM}, \mathrm{BM}, \mathrm{KJ}$; Acquisition, analysis and interpretation of data: DN, MM, BM, KJ; Drafting the article: DN, MM, BM, KJ; Revising the article critically for intellectual content: DN, MM, BM, KJ; Approved final version of the manuscript: DN, MM, BM, KJ.

Conflict of interest: The authors declare that they have no conflict of interest.

\section{References}

1. Fisher R, Acevedo C, Arzimanoglou A, Bogacz A, Cross JH, Elger CE, et al. ILAE official report. A practical clinical definition of epilepsy. Epilepsia. 2014;55(4):475-82.

2. Banerjee PN, Filippi D, Hauser WA. The descriptive epidemiology of epilepsy-a review. Epilepsy Res. 2009:85(1):31-45.

3. Temkin O. The Falling Sickness: A History of Epilepsy from the Greeks to the Beginnings of Modern Neurology. N Engl J Med. 1994;331:817.

4. Calmeil LF. De l'epilepsie etudee sous le rapport de son siege et de son influence sur la production de l' alienation mental. Paris. 1824.

5. Gowers WR. Epilepsies and other chronic convulsive diseases: their causes, symptoms and treatment. London: Churchill, JA. 1881.

6. Friedmann M. Uber die nichtepileptischen absencen oder kurzen narkoleptischen anfalle. Dtsch Z Nervenheilk. 1906;30:462-92.

7. Sauer H. Uber gehaufte kleine anfalle by kindern (pyknolepsie). Mschr Psychiat Neurol. 1916;40:276-300.

8. Yalcın O. Genes and molecular mechanisms involved in the epileptogenesis of idiopathic absence epilepsies. Seizure. 2012;21:79-86.

9. Blumenfeld H. Cellular and network mechanism of spike-wave discharges. Epilepsia. 2005;46:2133.

10. Fritschy JM, Brunig I. Formation and plasticity of GABAergic synapses: physiological mechanisms and pathophysiological implications. Pharmacol Ther. 2003;98:299-323.

11. Frugier G, Coussen F, Giraud MF, Odessa MF, Emerit MB, Boue'-Grabot E, et al. A gamma 2 
(R43Q) mutations, linked to epilepsy in humans, alters GABAA receptor assembly and modifies subunit composition on the cell surface. J Biol Chem. 2007;282:3819-28.

12. Jasper HH, Droogleever-Fortuyn J. Experimental studies on the functional anatomy of petit mal epilepsy. Assoc Res Nerv Ment Dis. 1947;26:272-98.

13. Williams, D. A study of thalamic and cortical rhythms in petit mal. Brain. 1953;76:50-69.

14. Panayiotopoulos CP. Absence epilepsies. In: Engel J Jr, Pedley TA, editors. Epilepsy: A Comprehensive Textbook. Philadelphia, PA: Lippincott-Raven; 1997. p. 2327-46.

15. Caraballo RH, Fontana E, Darra F, Bongiorni L, Fiorini E, Cersosimo R, et al. Childhood absence epilepsy and electroencephalographic focal abnormalities with or without clinical manifestations. Seizure. 2008;17(7):617-24.

16. Berg A, Berkovic S, Brodie MJ, Buchhalter J, Cross $\mathrm{JH}$, van Emde Boas W, et al. Revised terminology and concepts for organization of seizures and epilepsies: Report of the ILAE Commission on Classification and Terminology, 2005 - 2009. Epilepsia. 2010;51(4):676-85.

17. Panayiotopoulos CP. Treatment of Typical Absence Seizures and Related Epileptic Syndromes. Paediatr Drugs. 2001;3(5):379-403.

18. Tenney J, Glauser T. The Current State of Absence Epilepsy: Can We Have Your Attention? Epilepsy Curr. 2013;13(3):135-40.

19. Panayiotopoulos CP, Engel J. Atypical absence seizures. MedLink Neurology. 1999, October [updated 2015 November 28, cited 2016 May 25]; Available from: http://www.medlink.com/article/ atypical_absence_seizures.

20. Joshi CN, Patrick J. Eyelid myoclonia with absences: routine EEG is sufficient to make a diagnosis. Seizure. 2007;16(3):254-60.
21. Matricardi S, Verrotti A, Charelli F, Cerminara C, Curatolo P. Current advances in childhood absence epilepsy. Pediatr Neurol. 2014;50(3):205-12.

22. Kim HR, Kim GH, Eun SH, Eun BL, Byeon JH. Therapeutic Outcomes and Prognostic Factors in Childhood Absence Epilepsy. J Clin Neurol. 2016;12(2):160-5.

23. Verrotti A, Cerminara C, Domizio S, Mohn A, Franzoni E, Coppola G, et al. Levetiracetam in absence epilepsy. Dev Med Child Neurol. 2008;50(11):850-3.

24. Berg AT, Levy SR, Testa FM, Blumenfeld H. Long-term seizure remission in childhood absence epilepsy: might initial treatment matter? Epilepsia. 2014;55(4):551-7.

25. Danhofer P, Brázdil M, Ošlejšková H, Kuba R. Long-term seizure outcome in patients with juvenile absence epilepsy; a retrospective study in a tertiary referral center. Seizure. 2014;23(6):443-47.

26. Japaridze G, Kasradze S, Lomidze G, Zhizhiashvili L, Kvernadze D, Geladze K, et al. Focal EEG features and therapeutic response in patients with juvenile absence and myoclonic epilepsy. Clin Neurophysiol. 2016;127(2):1182-7.

27. Asadi-Pooya AA, Farazdaghi M. Seizure outcome in patients with juvenile absence epilepsy. Neurol Sci. 2016;37(2):289-92.

28. Cerminara C, D’Agati E, Casarelli L, Kaunzinger I, Lange KW, Pitzianti M, et al. Attention impairment in childhood absence epilepsy: An impulsivity problem? Epilepsy Behav. 2013;27(2):337-41.

29. D’Agati E, Cerminara C, Casarelli L, Pitzianti $\mathrm{M}$, Curatolo P. Attention and executive functions profile in childhood absence epilepsy. Brain Dev. 2012;34(10):812-17.

30. Vega C, Vestal M, DeSalvo M, Berman R, Chung $\mathrm{M}$, Blumenfeld $\mathrm{H}$, et al. Differentiation of attention-related problems in childhood absence epilepsy. Epilepsy Behav. 2010;19(1):82-5. 